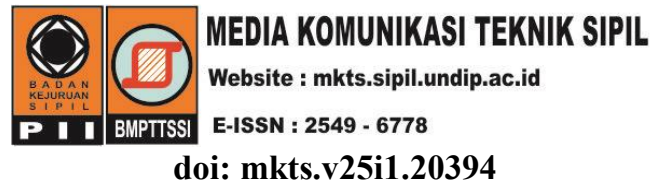

\title{
Perilaku Runtuh Balok Beton Bertulang dengan Sengkang Welded Wire Fabric (WWF)
}

\author{
"I Ketut Sudarsana, Putu Deskarta, Putu Chandra Wira Sanjaya \\ Teknik Sipil, Universitas Udayana, \\ *) ksudarsana@unud.ac.id
}

Received: 21 September 2018 Revised: 10 Maret 2019 Accepted:13 Maret 2019

\begin{abstract}
The use of Welded Wire fabric (WWF) has been widely tested and proven to behave very well as stirrups in a column, but its behavior has not been widely known when used on beams. This research was conducted to evaluate the behavior of beams with stirrup reinforcement of WWF M4 grid. A total of nine beam specimens with dimensions of $330 \mathrm{~mm} \times 180 \mathrm{~mm} \times 1500 \mathrm{~mm}$ were made and tested under monotonic loading until failure loads with three variations of stirrup, where each variation was made of three beam specimens and four concrete cylinders. The concrete was a ready mix concrete with an average compressive strength of 22,875 $\mathrm{kN}$ at 28 days. Beams were tested on simply supported with two concentrated loads at a distance of $500 \mathrm{~mm}$ from each support. The loads was applied incrementally and the middle span deflections were recorded for each increase in loads. The test results show that the stirrups of WWF M4 grid on beam specimens can increase the shear capacity, stiffness and control the occurrence of the first inclined crack. When compared to conventional stirrups (BJTP Ø6mm), beams with WWF M4 stirrups show better behavior.
\end{abstract}

Keywords: Reinforced concrete beam, welded wire fabric (WWF), shear, stirrups

\begin{abstract}
Abstrak
Penggunaan welded wire fabric (WWF) telah banyak diuji dan terbukti dapat berperilaku sangat baik sebagai sengkang pada kolom, namun belum banyak diketahui perilakunya apabila dipergunakan pada balok. Penelitian ini dilakukan untuk mengevaluasi perilaku balok dengan tulangan sengkang grid WWF M4. Sebanyak sembilan buah benda uji balok dengan dimensi 330mm x 180mm x $1500 \mathrm{~mm}$ dibuat dan diuji dengan pembebanan monotonik sampai beban runtuh dengan tiga buah variasi sengkang, dimana setiap variasi dibuat benda uji sebanyak tiga buah balok dan empat buah silinder. Beton yang digunakan adalah beton ready mix dengan kuat tekan rata-rata 22,875 kN pada umur 28 hari. Balok diuji di atas perletakan sederhana dengan dua buah beban terpusat dengan jarak $500 \mathrm{~mm}$ dari masing-masing perletakan. Beban dikerjakan secara bertahap dan lendutan tengah bentang dicatat untuk setiap peningkatan beban. Hasil pengujian menunjukkan bahwa sengkang grid WWF M4 pada benda uji balok dapat meningkatkan kapasitas geser, kekakuan dan control terhadap terjadinya retak miring pertama. Jika dibandingkan dengan sengkang konvensional (BJTP $\varnothing$ 6mm), balok dengan sengkang grid WWF M4 menunjukkan perilaku yang lebih baik.
\end{abstract}

Kata kunci: Balok beton bertulang, welded wire fabric (WWF), geser, sengkang

\section{Pendahuluan}

Pada pelaksanaan konstruksi struktur beton bertulang melibatkan tiga komponen penting yaitu pembuatan cetakan (bekesting), pabrikasi baja tulangan dan material beton. Pabrikasi tulangan pada struktur beton bertulang terutama dalam pembuatan sengkang merupakan proses yang sangat penting agar tulangan memiliki pengangkuran yang memenuhi persyaratan untuk menghindari kegagalan dini (premature failure). Pengangkuran tulangan yang diperoleh dengan pembengkokan ujung sengkang dengan sudut $135^{\circ}$ sesui dengan persyaratan SNI 2847:2013 sering dilupakan karena pekerja ingin pekerjaan lebih cepat dan mudah dalam pemasangannya serta kurangnya pengawasan di lapangan. Hal ini sering dijumpai saat pelaksanaan konstruksi atau terlihat saat terjadi keruntuhan struktur akibat gempa. Keberadaan welded wire fabric (WWF) dapat 
menjadi alternatif tulangan sengkang pada balok beton bertulang untuk mengatasi bentuk hook ujung sengkang yang tidak 135 derajat.

Penggunaan WWF grid sebagai sengkang tertutup atau hoops pada kolom telah banyak dilakukan pengujian dan menunjukkan mampu berperilaku sangat baik sebagai tulangan geser dan pengekangan beton (Saatcioglu \& Grira, 1999; Tavio et al., 2012). Material ini juga telah banyak dipergunakan sebagai tulangan lentur pelat dan dinding beton. Penggunaan tulangan WWF sebagai tulangan longitudinal juga diteliti oleh Elsayed (2016) pada balok T dengan beban berulang.

Penelitian Elsayed (2016) ini menunjukkan penggunaan WWF mampu memberikan kontrol retak yang lebih baik serta dapat mengurangi lebar retak yang terjadi dengan memperlambat terjadinya retak pertama. Disamping itu, penggunaan tulangan WWF juga meningkatkan daktilitas balok. Tulangan sengkang WWF berbentuk U pada balok$\mathrm{T}$ baik pada beton prategang maupun non-prategang mampu berfungsi sama efektifnya dengan tulangan Sengkang konvensional dan memiliki pengangkuran yang baik dari dua buah tulangan diagonal (Mansur et al., 1987; Xuan et al., 1988).

Balok dengan sengkang WWF juga menunjukan kontrol retak diagonal yang lebih baik dengan distribusi yang lebih merata sehingga mampu memberikan regangan yang lebih tinggi pada sengkang (Mansur et al., 1987; Xuan et al., 1988, Griezic et al., 1994; Lin \& Perng, 1998). Namun, Sengkang WWF berbentuk U ini kurang efektif dalam hal jumlah perulangan apabila balok menerima beban berulang karena terjadinya kegagalan premature pada bagian sambungan las WWF. Hal ini mengakibatkan turunnya kapasitas geser balok (Pincheira et al., 1989; Elsayed, 2016).

Disamping sengkang U, tulangan Galvanized WWF dengan grid lebih kecil sering disebut welded wire mesh (WWM) juga pernah diteliti sebagai sengkang balok. Ajin \& Gokulram (2015) menunjukan bahwa balok beton normal dengan WWM grid 50,8mm x $50,8 \mathrm{~mm}$ sebagai tulangan geser menunjukan perilaku lentur balok dapat ditingkat dengan menggunakan WWM meskipun tidak menggunakan sengkang konvensional. Hasil yang sama juga disampaikan Nithin \& Kumar (2016) dimana perilaku lentur balok self-compacting concrete yang dibungkus sepanjang bentang menggunakan galvanized WWM ukuran $1,25 \mathrm{~mm}$ dan grid 25,4mm x 25,4mm dapat ditingkatkan.

Penambahan lapis WWM sebagai tambahan tulangan geser balok dapat meningkatkan kekuatan lentur, perilaku retak dan penyerapan energi secara significant (Nithin \& Kumar (2016). Alexander \& Ramakrishnan (2016) mengusulkan prosedur untuk mendesain balok beton bertulang dengan tulangan geser dari WWM. Sudarsana et al (2016) meneliti pemanfaatan galvanized WWF grid $50 \mathrm{~mm} \times 50 \mathrm{~mm}$ dan $100 \mathrm{~mm} \times 100 \mathrm{~mm}$ sebagai tulangan geser dan pengekangan pada kolom pendek penampang pipih dan menunjukan bahwa kapasitas dan daktilitas aksial kolom penampang pipih dengan WWM sebanding dengan kolom menggunakan tulangan konvensional.

Sebagian besar penelitian-penelitian sebelumnya menggunakan WWF sebagai sengkang balok dalam bentuk $U$ atau galvanized WWM yang membungkus tulangan longitudinal. Belum ditemukan pustaka yang menggunakan WWF grid seperti pada kolom dipergunakan sebagai sengkang tertutup balok. Penelitian ini dilakukan untuk mengevaluasi perilaku balok dengan tulangan geser WWF grid dibandingkan dengan tulangan geser konvensional. Prediksi kekuatan geser peraturan (SNI 2817:2013) dievaluasi untuk balok dengan tulangan geser WWF grid.

\section{Prediksi kapasitas geser balok}

Kapasitas geser dari balok beton bertulang dengan tulangan transversal diperoleh dari penjumlahan kontribusi beton utuh $\left(\mathrm{V}_{\mathrm{cz}}\right)$, agregat interlock $\left(\mathrm{V}_{\mathrm{ay}}\right)$, aksi pasak tulangan longitudinal (Vd) dan tulangan transversal $\left(\mathrm{V}_{\mathrm{s}}\right.$ ) (Park \& Paulay, 1975; Wight \& MacGregor, 2012). Pada kondisi retak yang semakin lebar, maka kontribusi Vay mengakibat peningkatan kontribusi $\mathrm{Vd}$ dan $\mathrm{Vcz}$ yang cepat sampai terjadinya kegagalan berupa pecahnya beton pada tulangan longitudinal atau splitting failure atau beton hancur pada daerah tekan. Semua komponen kecuali Vs memiliki perilaku yang getas sehingga sangat sulit memperhitungkannya pada proses disain, sehingga nilai-nilai dari $\mathrm{V}_{\mathrm{cz}}, \mathrm{V}_{\mathrm{ay}}$ dan $\mathrm{V}_{\mathrm{d}}$ digabungkan menjadi $\mathrm{V}_{\mathrm{c}}$ sebagai kontribusi dari beton secara keseluruhan (Wight \& MacGregor, 2012).

Standar Nasional Indonesia (SNI 2847:2013) memperhitungkan kapasitas geser balok beton bertulang $\left(\mathrm{V}_{\mathrm{n}}\right)$ merupakan kontribusi dari beton $\left(\mathrm{V}_{\mathrm{c}}\right)$ dan tulangan transversal $\left(\mathrm{V}_{\mathrm{s}}\right)$ seperti Persamaan 1, 2, dan 3. Adapun retak geser diagonal dianggap membentuk sudut $45^{\circ}$ dengan sumbu memanjang balok.

$V_{n}=V_{c}+V_{s}$

dengan

$V_{c}=0,17 \lambda \sqrt{f_{c}^{\prime}} b d$ 
$V_{s}=\frac{A_{v} f_{y} d}{s}$

dimana $\lambda$ adalah faktor modifikasi untuk beton ringan, $f_{c}$ adalah kuat tekan beton, $b$ adalah lebar balok, $\mathrm{d}$ adalah tinggi efektif balok, $\mathrm{A}_{\mathrm{v}}$ adalah luas kaki-kaki vertikal tulangan tranversal, $\mathrm{f}_{\mathrm{y}}$ adalah tegangan leleh tulangan transversal dan s adalah jarak atar tulangan transversal.

\section{Metode}

\section{Properti material}

Beton yang dipergunakan dalam penelitian ini diperoleh dari perusahaan ready mix di Bali. Ratarata hasil pengujian uniaxial tekan terhadap empat buah silinder beton yang memenuhi standar ASTM pada umur 28 hari adalah 22,85 MPa. Baja tulangan ulir (BJTD) $13 \mathrm{~mm}$, BJTP $\varnothing 6 \mathrm{~mm}$ dan WWF grid $150 \mathrm{~mm} \times 150 \mathrm{~mm}$ dengan $\emptyset 4 \mathrm{~mm}$ (WWF M4) yang digunakan memiliki tegangan leleh $\left(f_{y}\right)$ dan tegangan tarik maksimum $\left(\mathrm{f}_{\mathrm{su}}\right)$ adalah berturut-turut 469,78 MPa dan 576,08 MPa untuk D13; 409,43 MPa dan 553,70 MPa untuk 6mm; 424,54 MPa dan 439,38 MPa untuk WWF M4.

Pengujian kuat tekan beton, pengujian kuat tarik baja tulangan dan pengujian kuat tarik WWF ini dilakukan di Laboratorium Program Studi Teknik Sipil, Fakultas Teknik, Universitas Udayana, Bali.

\section{Pembuatan benda uji balok}

Pada penelitian ini menggunakan benda uji balok penampang persegi panjang yang memiliki dimensi $180 \mathrm{~mm} \times 330 \mathrm{~mm}$ x $1500 \mathrm{~mm}$ sebanyak sembilan buah dengan tinggi dan lebar balok disesuaikan dengan ukuran grid WWF yang ada di pasaran yaitu $150 \mathrm{~mm} \times 150 \mathrm{~mm}$. Adapun parameter yang ditinjau adalah balok tanpa tulangan geser (tiga buah benda uji kontrol B-11, B-12 dan B-13), balok dengan tulangan geser BJTP $\varnothing 6 \mathrm{~mm}$ (tiga buah benda uji B21, B-22, B-23) dan balok dengan tulangan geser WWF M4 (tiga buah benda uji B-31, B-32, B-33). Semua benda uji adalah balok bertulangan tunggal dengan tulangan tarik 2D13 dengan penutup beton bersih $15 \mathrm{~mm}$. Balok didesain memiliki tulangan geser yang memenuhi persyaratan SNI 2847:2013. Tulangan geser WWF dipasang dalam bentuk grid yang menyerupai pemasangan sengkang pada kolom. Pengangkuran kaki vertikal sengkang diberikan oleh tiga buah tulangan melintang. Setiap parameter yang ditinjau dibuat tiga buah benda uji balok dengan detail pemasangan tulangan seperti terlihat pada Gambar 1. Semua benda uji dicor pada saat yang bersamaan dengan proporsi campuran beton yang sama. Perawatan benda uji dilakukan dengan menutup permukaan balok dengan karung goni basah dan plastik untuk mengurangi terjadinya penguapan air selama tujuh hari. Setelah itu cetakan beton dibuka dan balok disimpan pada suhu ruangan dan terhindar dari benturan sampai waktu pengujian.

\section{B-1:Benda Uji Kontrol-tanpa tulangan geser, sebanyak 3 buah}
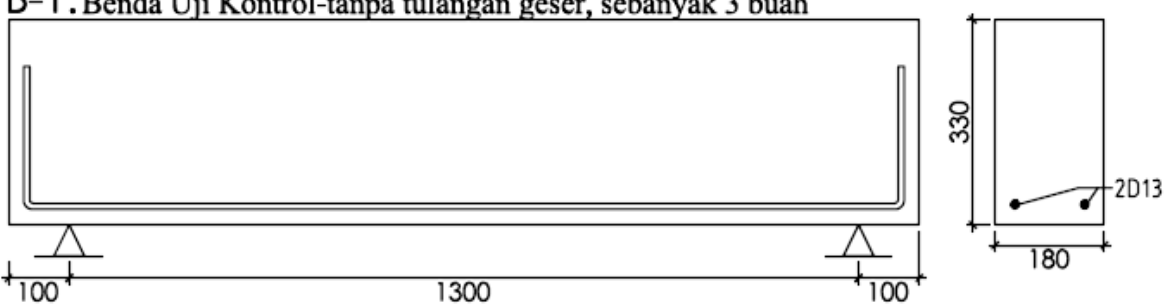

B-2: Benda Uji dengan sengkang BJTP $6 \mathrm{~mm}$, Sebanyak 3 buah
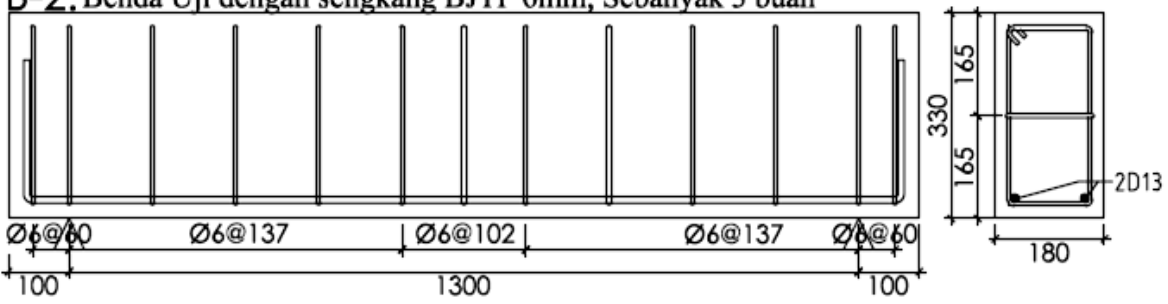

B-3: Benda Uji dengan sengkang WWF M4, Sebanyak 3 buah

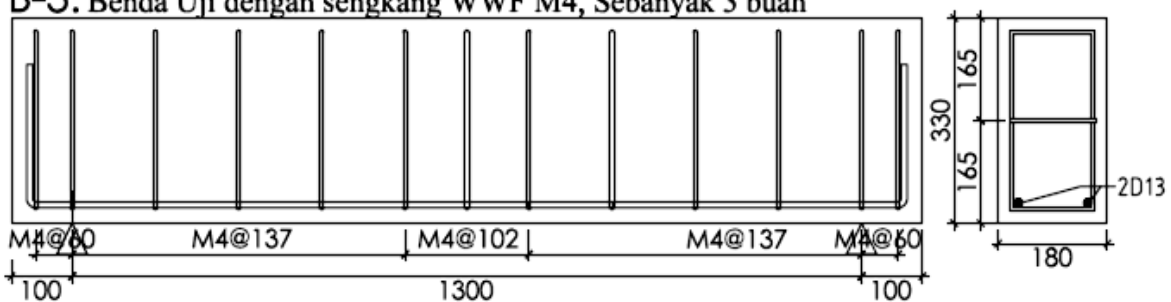

Gambar 1. Dimensi dan detail tulangan benda uji balok 


\section{Setup pengujian}

Pengujian benda uji balok dilakukan setelah beton berumur 28 hari. Pengujian dilakukan di atas perletakan sederhana sendi dan rol dengan dua titik pembebanan sejarak $500 \mathrm{~mm}$ dari tumpuan seperti pada terlihat pada Gambar 2. Pengukuran lendutan di tengah bentang balok untuk setiap peningkatan beban menggunakan dua buah mechanical (dial) gauges yang diletakan pada kedua sisi samping balok setinggi lokasi tulangan tarik dari dari sisi tarik terluar balok.

Beban ditingkatkan secara bertahap dengan peningkatan 2,5 kN sampai terjadinya indikasi leleh baja tulangan kemudian beban disesuaikan dengan peningkatan lendutan yang terjadi, sampai balok mengalami keruntuhan (failure). Lendutan tengah bentang dicatat secara manual dari dial gauges untuk setiap peningkatan beban dan direkam dengan vidio recorder selama pelaksanaan pengujian. Hal ini perlu dilakukan untuk mengecek ulang hasil pembacaan manual yang diperoleh. Terbentuknya retak selama proses pembebanan dicatat dan ditandai pada benda uji untuk setiap peningkatan beban.

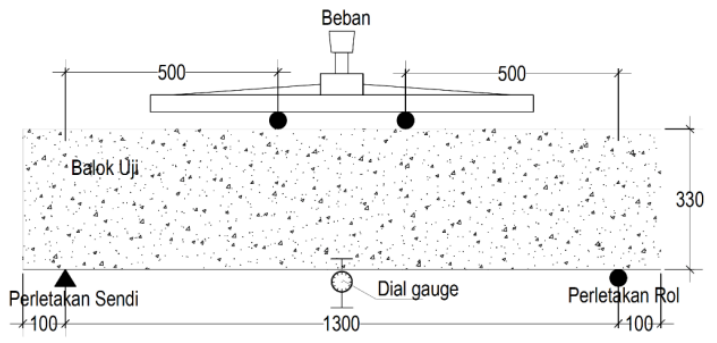

a. Setup pengujian benda uji

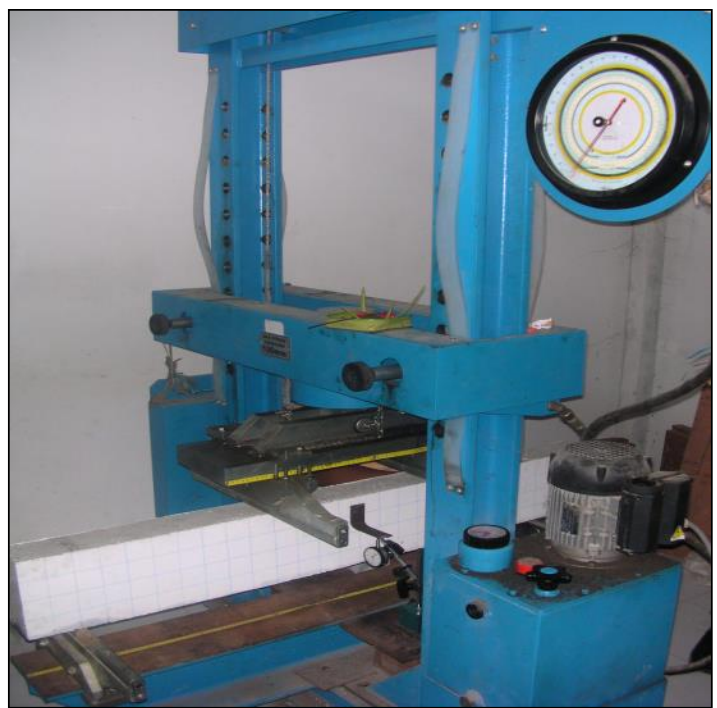

b. Mesin uji lentur

Gambar 2. Setup pengujian dan peralatan yang digunakan

\section{Hasil dan Pembahasan}

\section{Mode keruntuhan dan pola retak}

Secara umum, seluruh benda uji mengalami kegagalan geser yang diawali dengan terbentuknya retak rambut diagonal dengan sudut $\pm 45^{\circ}$ pada daerah tumpuan balok. Retak diagonal tersebut semakin melebar dan memanjang menuju titik pembebanan dengan peningkatan beban yang bekerja sampai akhirnya terjadi kegagalan geser. Pola retak salah satu benda uji dari masing-masing variasi setelah mengalami keruntuhan dapat dilihat pada Gambar 3. Jumlah retak yang terjadi pada benda uji dengan sengkang BJTP $\varnothing 6 \mathrm{~mm}$ lebih banyak daripada benda uji dengan sengkang WWF M4 terutama retak vertikal (retak lentur). Ini menunjukan WWF mampu memberikan kontrol retak yang lebih baik.

Gaya geser yang menyebabkan terjadinya retak miring pertama kali $\left(\mathrm{V}_{\mathrm{cr}}\right)$ adalah rata-rata sebesar $30,83 \mathrm{kN}, 31,67 \mathrm{kN}$ dan 35,00 kN masing-masing untuk benda uji tanpa sengkang, dengan sengkang BJTP Ø6mm dan dengan sengkang WWF M4. Ini menunjukkan terjadi peningkatan gaya geser retak miring pertama (Vcr) sebesar 2,72\% dan $13,53 \%$ dari balok tanpa tulangan geser untuk masingmasing balok dengan tulangan Sengkang BJTP $\emptyset 6 \mathrm{~mm}$ dan WWF M4mm.

Retak miring yang terjadi pada balok dengan WWF memerlukan gaya geser yang lebih besar sehingga terjadinya lebih lambat dibandingkan dengan balok Sengkang BJTP Ø6mm. Hal ini menunjukkan bahwa WWF mampu memberikan kontrol terjadinya retak lebih baik. Perilaku ini juga sesuai dengan hasil penelitian dari Mansur et al (1987); Xuan et al (1988); Griezic et al (1994); Lin \& Peng (1998); Elsayed (2016).

\section{Hubungan beban dan Lendutan}

Lendutan di tengah-tengah bentang balok diukur dengan menggunakan dua buah dial gauge yang ditempatkan pada kedua sisi balok yang sejajar dengan posisi tulangan longitudinal. Hasil rata-rata pencatatan dari kedua dial gauge tersebut kemudian diplot terhadap beban yang diaplikasikan pada saat pengujian seperti terlihat pada Gambar 4. Semua variasi dibandingkan dengan benda uji kontrol. Diagram beban-lendutan menunjukan bahwa sebelum retak terjadi, balok masih berperilaku linear yang ditunjukkan dengan perilaku kurva hubungan beban dan lendutan balok masih mendekati garis lurus. Beban yang terus ditingkatkan mengakibatkan tegangan tarik beton terlewati sehingga terjadi retak. 


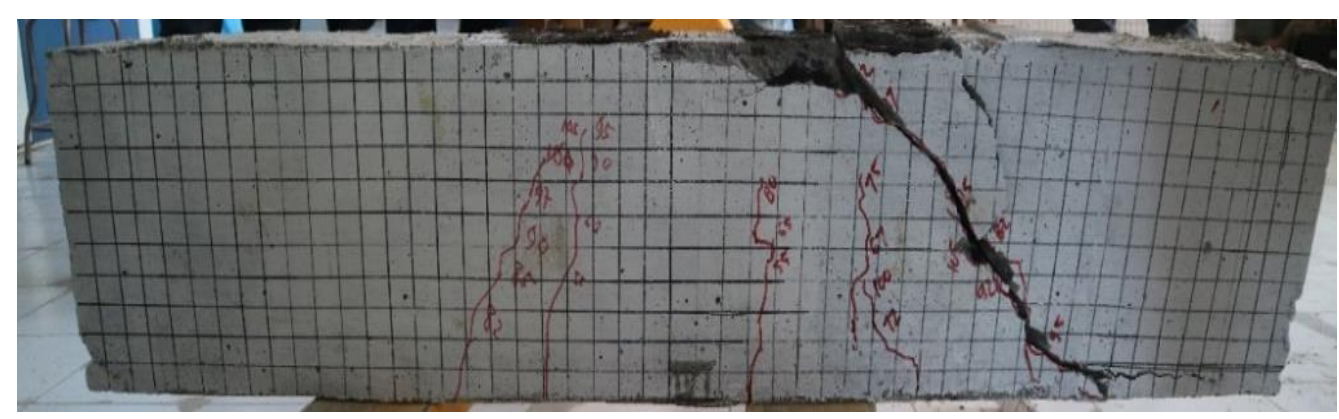

a. Balok tanpa tulangan geser (tipe B-1)

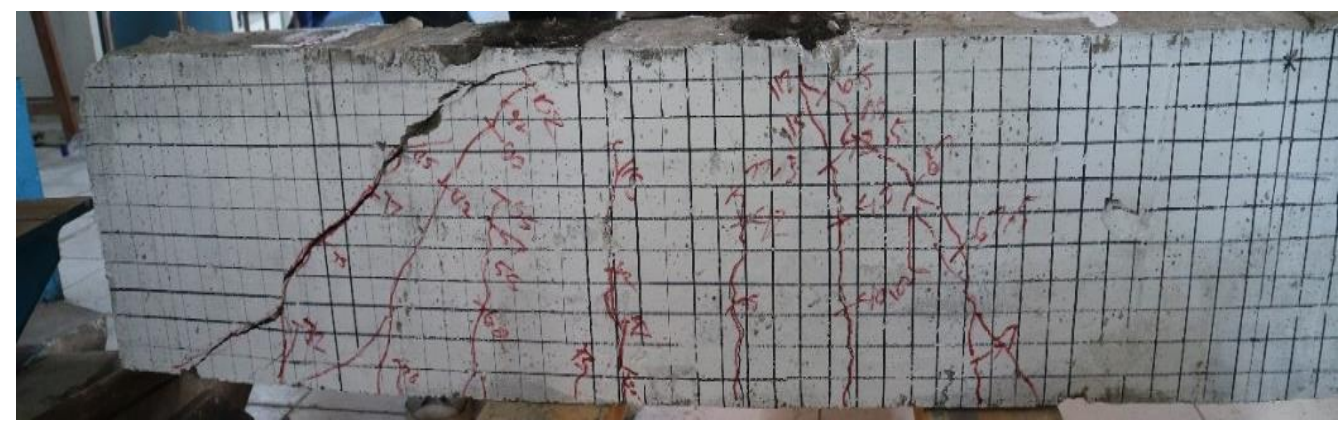

b. Balok dengan tulangan geser BJTP Ø6mm (Tipe B-2)

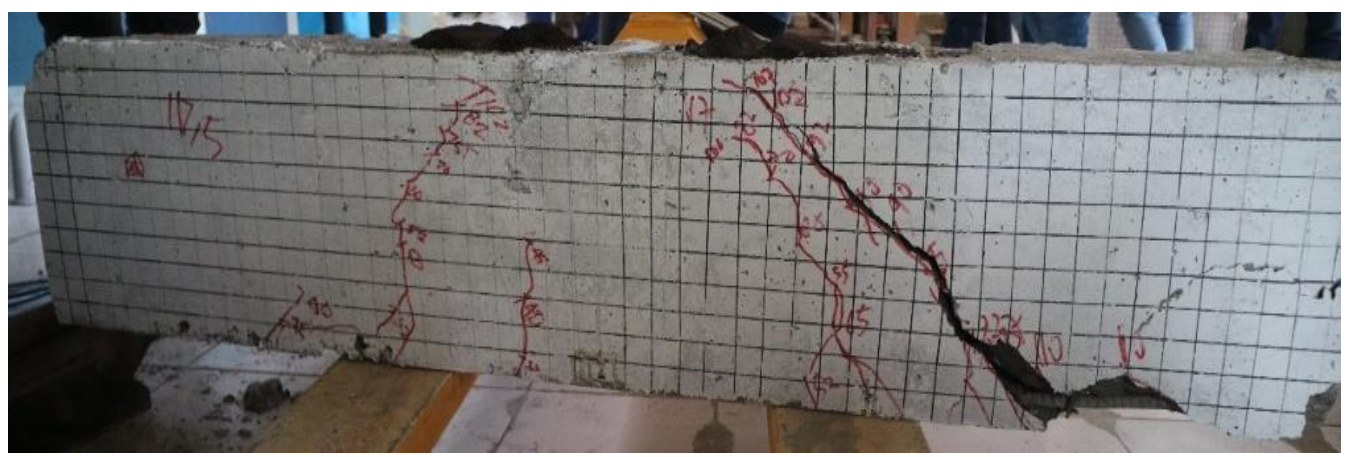

(c) Balok dengan tulangan geser WWF M4 (Tipe B-3)

Gambar 3. Contoh pola keruntuhan benda uji balok setelah pengujian untuk setiap variasi sengkang

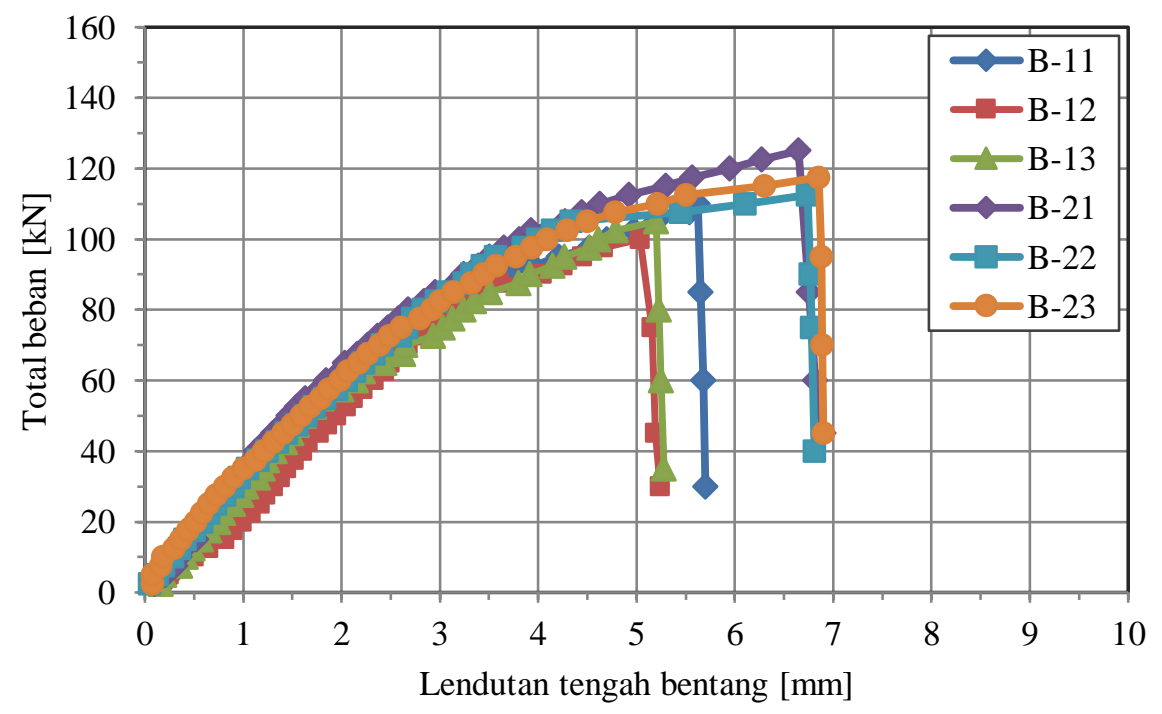

a. Balok kontrol dan tulangan geser BJTP $6 \mathrm{~mm}$ 


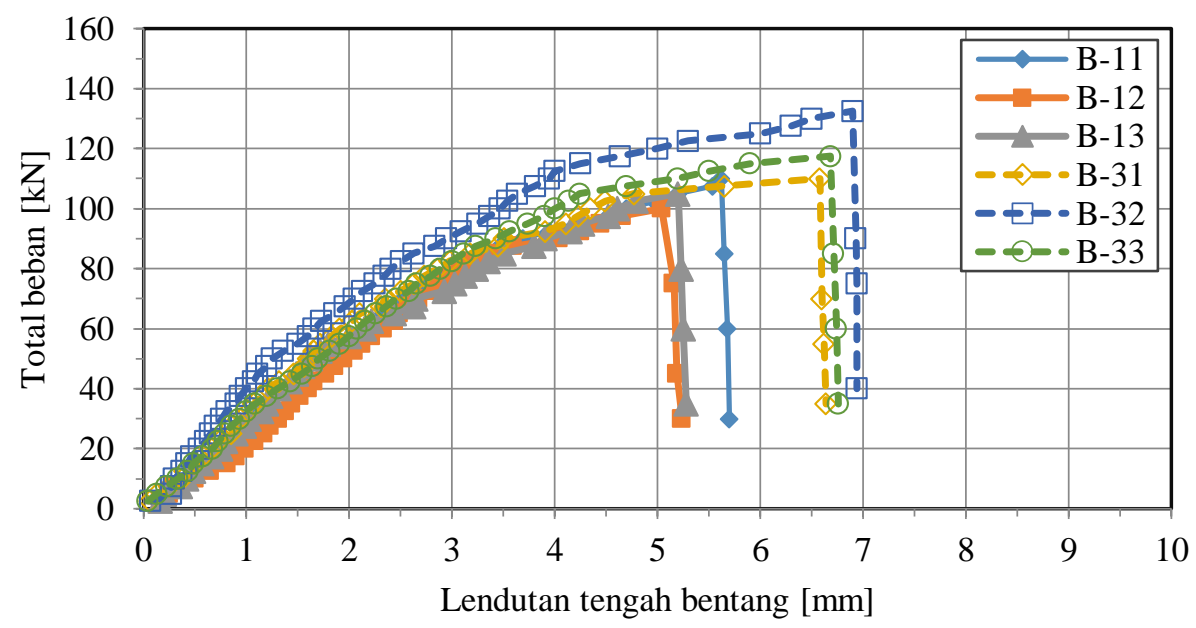

b. Balok kontrol dan tulangan geser WWF M4

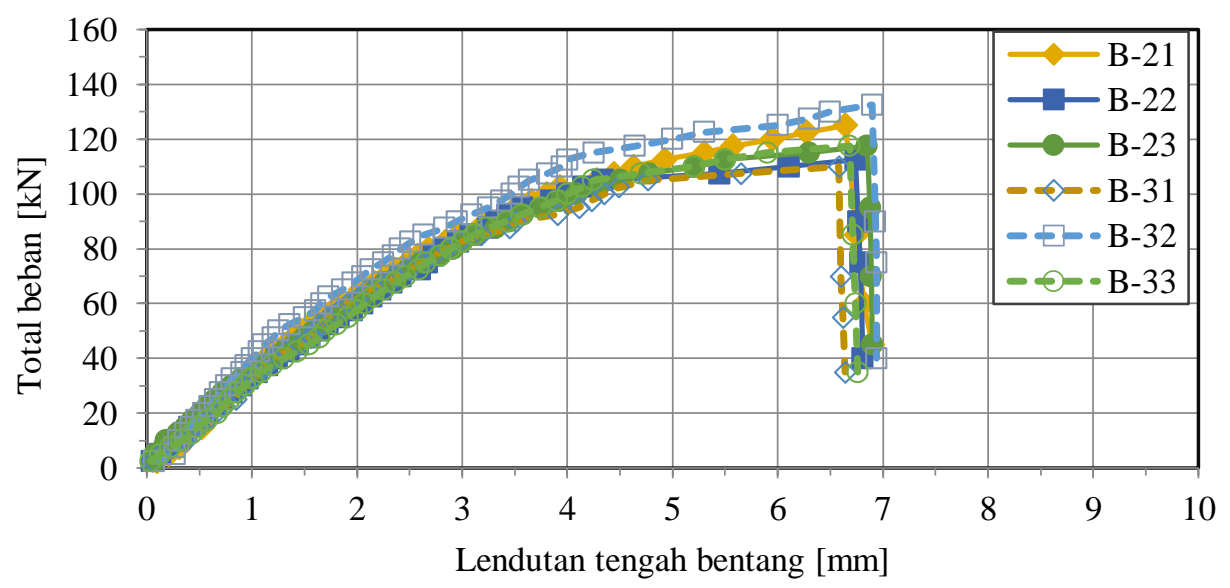

\section{c. Perbandingan lendutan antara balok dengan BJTP $\varnothing 6 \mathrm{~mm}$ dan WWF M4}

Gambar 4. Hubungan beban dan lendutan tengah bentang benda uji B-1, B-2 dan B-3

Akibat retak yang terjadi pada balok baik retak lentur maupun retak geser, maka kurva lendutan mengalami perubahan menjadi nonlinear yang akhirnya turun secara tiba-tiba saat balok mengalami kegagalan

Kegagalan yang secara tiba-tiba merupakan indikasi bahwa semua benda uji mengalami keruntuhan geser. Kurva beban-lendutan ini tidak menunjukan adanya kondisi yield plateu tulangan longitudinal atau terjadinya peningkatan lendutan tanpa peningkatan beban yang significant sehingga dapat dikatakan bahwa tulangan longitudinal mungkin belum mengalami leleh pada saat balok mengalami keruntuhan. Kondisi keruntuhan balok seperti ini merupakan keruntuhan geser murni seperti yang diharapkan saat mendesain benda uji agar murni keruntuhan akibat gaya geser. Semua benda uji dengan tulangan geser (baik BJTP BJTP Ø6mm maupun WWF M4 mm) mengalami lendutan yang lebih besar dibandingkan dengan benda uji tanpa tulangan geser atau balok kontrol.Kondisi ini terjadi karena tulangan transversal memberikan kontribusi dalam peningkatan beban yang bekerja. Dengan peningkatan beban ini maka kapasitas gesernya juga mengalami peningkatan terlepas dari penggunaan sengkang konvensional BJTP Ø6mm maupun WWF M4. Penggunaan tulangan geser dari WWF (Balok B-3) menghasilkan perilaku yang hampir sama dengan tulangan geser baja polos (Balok B-2) seperti terlihat pada Gambar 4c sehingga pemanfaatkan WWF sebagai tulangan geser balok dapat dipertimbangkan sebagai alternatifnya apabila pembuatan kait ujung (hooks) pada sengkang konvensional untuk memenuhi persyaratan pada code menjadi suatu kendala.

\section{Kapasitas geser balok}

Kapasitas geser semua balok pada kondisi retak $\left(\mathrm{V}_{\mathrm{cr}}\right)$ dan runtuh $\left(\mathrm{V}_{\max }\right)$ dari hasil pengujian sembilan buah benda uji balok ditampilkan pada Tabel 1. Retak miring baru terjadi setelah gaya geser bekerja lebih dari $50 \%$ dari gaya geser maksimum. 
Tabel 1. Kapasitas geser benda uji balok dan perbandingannya dengan prediksi SNI 2847:2013

\begin{tabular}{|c|c|c|c|c|c|c|c|c|c|}
\hline \multirow[b]{2}{*}{ No } & \multirow[b]{2}{*}{ Kode } & \multicolumn{6}{|c|}{ Hasil penelitian } & \multirow[b]{2}{*}{$\begin{array}{c}\mathbf{V}_{\text {sni }} \\
(\mathbf{k N})\end{array}$} & \multirow[b]{2}{*}{$\begin{array}{c}\text { Rasio } \\
\mathbf{V}_{\max } / \mathbf{V}_{\text {sni }}\end{array}$} \\
\hline & & $\begin{array}{c}\mathbf{P}_{\mathbf{c r}} \\
(\mathbf{k N})\end{array}$ & $\begin{array}{l}\mathbf{P}_{\max } \\
(\mathbf{k N})\end{array}$ & $\begin{array}{c}\mathbf{V}_{\mathbf{c r}} \\
(\mathbf{k N})\end{array}$ & $\begin{array}{c}\mathrm{V}_{\mathrm{cr}}, \\
\text { rata- } \\
\text { rata } \\
(\mathrm{kN})\end{array}$ & $\begin{array}{l}V_{\max } \\
(\mathbf{k N})\end{array}$ & $\begin{array}{l}\mathrm{V}_{\max }, \\
\text { rata- rata } \\
(\mathrm{kN})\end{array}$ & & \\
\hline \multirow{3}{*}{1} & B-11 & 60,0 & 110,0 & 30,00 & \multirow{3}{*}{30,83} & 55,00 & & \multirow{3}{*}{44,54} & \multirow{3}{*}{1,18} \\
\hline & B-12 & 62,5 & 100,0 & 31,25 & & 50,00 & 52,50 & & \\
\hline & B-13 & 62,5 & 105,0 & 31,25 & & 52,50 & & & \\
\hline \multirow{3}{*}{2} & B-21 & 60,0 & 125,0 & 30,00 & \multirow{3}{*}{31,67} & 62,50 & & \multirow{3}{*}{95,97} & \multirow{3}{*}{0,62} \\
\hline & B-22 & 62,5 & 112,5 & 31,25 & & 56,25 & 59,16 & & \\
\hline & B-23 & 67,5 & 117,5 & 33,75 & & 58,75 & & & \\
\hline \multirow{3}{*}{3} & B-31 & 72,5 & 110,0 & 36,25 & \multirow{3}{*}{35,00} & 55,00 & & \multirow{3}{*}{68,24} & \multirow{3}{*}{0,88} \\
\hline & B-32 & 67,5 & 132,5 & 33,75 & & 66,25 & 60,00 & & \\
\hline & B-33 & 70,0 & 117,5 & 35,00 & & 58,75 & & & \\
\hline
\end{tabular}

Tabel 2. Kekakuan benda uji

\begin{tabular}{|c|c|c|c|c|c|}
\hline \multirow[b]{2}{*}{ No } & \multirow[b]{2}{*}{ Kode } & \multicolumn{2}{|c|}{ Kondisi elastis $\left(k_{e}\right)$} & \multicolumn{2}{|c|}{ Kondisi plastis $\left(k_{p}\right)$} \\
\hline & & $P / \delta(\mathbf{k N} / \mathbf{m m})$ & 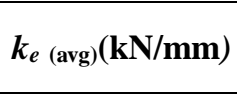 & $\begin{array}{c}P / \delta \\
(\mathrm{kN} / \mathrm{mm})\end{array}$ & $k_{p \text { (avg) }}(\mathrm{kN} / \mathrm{mm})$ \\
\hline 1 & B-11 & 27,64 & & - & - \\
\hline 2 & B-12 & 25,61 & 27,35 & - & \\
\hline 3 & B-13 & 28,80 & & - & \\
\hline 4 & B-21 & 32,52 & & 18,81 & \\
\hline 5 & B-22 & 29,27 & 30,52 & 16,69 & 15,91 \\
\hline 6 & B-23 & 29,80 & & 12,23 & \\
\hline 7 & B-31 & 24,13 & & 15,42 & \\
\hline 8 & B-32 & 34,43 & 29,00 & 15,77 & 16,25 \\
\hline 9 & B-33 & 28,45 & & 17,57 & \\
\hline
\end{tabular}

Tulangan geser WWF M4 mampu memberikan $\mathrm{V}_{\mathrm{cr}}$ yang lebih besar sehingga kemunculan retak geser dapat diperlambat bila dibandingkan dengan balok kontrol dengan tulangan sengkang BJTD. Rata-rata kapasitas geser maksimum balok $\left(\mathrm{V}_{\max }\right)$ dengan sengkang WWF M4 sedikit lebih besar dibandingkan dengan balok bertulangan sengkang BJTP Ø6mm.

Perbedaan kapasitas geser ini merupakan kontribusi dari perbedaan kuat leleh WWF yang lebih tinggi sebesar 4,18\% daripada kuat leleh BJTP $\emptyset 6 \mathrm{~mm}$ meskipun pada desain awal tulangan geser sudah dilakukan konversi diameter tulangan sehingga diperoleh nilai rasio luas tulangan gesernya (Av/s) sebesar 0,413 dan 0,183 masing-masing untuk balok dengan sengkang BJTP $\varnothing 6 \mathrm{~mm}$ atau B-2 dan dengan sengkang WWF M4 atau B-3. Perbandingan antara kapasitas geser maksimum pengujian dan prediksi geser menurut SNI 2847:2013 $\left(\mathrm{V}_{\text {maks }} / \mathrm{V}_{\text {sni }}\right)$ sesuai dengan Persamaan 1, 2 dan 3 terlihat bahwa hanya balok tanpa tulangan geser yang diprediksi aman dengan rasio $\mathrm{V}_{\text {maks }} / \mathrm{V}_{\text {sni }}$ sebesar 1,18 , sedangkan kedua variasi balok dengan tulangan geser BJTP Ø6mm dan WWF M4 memiliki kapasitas geser lebih kecil dari prediksi SNI 2847:2013 sehingga prediksi SNI 2847 untuk kedua tipe balok ini tidak aman yang ditunjukkan dengan nilai rata-rata rasio $\mathrm{V}_{\text {maks }} / \mathrm{V}_{\text {sni }}$ lebih kecil daripada 1,0. Hal ini diakibatkan oleh prediksi SNI 2847:2013 terhadap kontribusi tulangan geser pada kapasitas geser balok jauh lebih besar daripada yang terjadi pada saat pengujian.

\section{Kekakuan balok}

Kekakuan setiap benda uji (k) dapat dihitung dari diagram hubungan beban dan lendutan yang ditampilkan pada Gambar 4 dengan menggunakan persamaan $\mathrm{k}=\mathrm{P} / \delta$, dengan $\mathrm{k}=$ besar kekakuan, $\mathrm{P}=$ besar gaya yang diterima balok, $\delta=$ besarnya lendutan yang terjadi. Berdasarkan bentuk diagram $\mathrm{P}$ - $\delta$ maka kekakuan benda uji dapat dibagi menjadi dua kondisi yaitu kondisi elastis $\left(\mathrm{k}_{\mathrm{e}}\right)$ dimana kondisi dari origin sampai titik perubahan kurva linear ke nonlinear dan kondisi plastis $\left(\mathrm{k}_{\mathrm{p}}\right)$ dimana kondisi dari titik mulai kurva nonlinear sampai runtuh atau beban maksimum. Hasil perhitungan kekakuan $(\mathrm{k})$ dari masing-masing benda uji dan rata-ratanya dapat dilihat pada Tabel 2. Kekakuan rata-rata balok dengan sengkang WWF M4 dan BJTD Ø6mm tidak berbeda cukup besar baik pada kondisi elastis $\left(\mathrm{k}_{\mathrm{e}, \mathrm{avg}}\right)$ maupun pada kondisi ( $\mathrm{k}_{\mathrm{p}, \mathrm{avg}}$ ). Pada kondisi elastis, kekakuan balok sengkang BJTD Ø6mm adalah 5,2\% lebih besar daripada kekauan balok dengan Sengkang WWF M4, namun balok dengan 
sengkang WWF M4 lebih besar 2,1\% pada kondisi plastis. Dilihat dari perbedaan kekakuan ini, perilaku balok menggunakan sengkang BJTD Ø6mm ataupun WWF M4 tidak berbeda secara significant sehingga material WWF dapat dipergunakan sebagai tulangan geser apabila dilihat dari kekakuan balok itu sendiri. Nilai kekakuan balok ini juga dapat memebrikan gambaran tentang daktilitas dari benda uji. Dengan nilai kekakuan yang tidak berbeda antara benda uji balok menggunakan tulangan transversal BJTP $\varnothing 6 \mathrm{~mm}$ dengan balok menggunakan tulangan transversal WWF M4, maka daktilitas kedua balok tersebut juga memiliki daktilitas yang hampir sama.

\section{Kesimpulan}

Berdasarkan hasil pengujian dan pembahasan yang telah dilakukan maka dapat diambil beberapa kesimpulan yaitu (1). Penggunaan tulangan sengkang grid WWF M4 dapat meningkatkan kapasitas geser nominal balok dan dapat memperlambat terjadinya retak miring pertama. (2). Pola retak yang dihasilkan dari penggunaan tulangan sengkang grid WWF M4 lebih baik daripada balok Sengkang konvesional BJTP 6mm dengan beban retak yang lebih besar. (3). Kurva beban dan lendutan dari balok dengan sengkang grid WWF M4 memiliki bentuk yang mirip dengan balok bertulangan sengkang BJTP Ø6mm. (4). Kekakuan elastis balok dengan Sengkang BJTP $\varnothing 6 \mathrm{~mm}$ lebih besar 5,2\% namun pada kondisi plastis lebih kecil $2,1 \%$ dari kekakuan balok dengan Sengkang WWF M4.

\section{Daftar Pustaka}

Ajin, M. \& Gokulram, H. (2015). Flexural Behaviour of RC Beam with Welded Mess as Shear Reinforcement. Int. J. of Eng. Sciences and Research Tech. (IJESRT), 4(3), 242-246.

Alexander, D. \& Ramakrishnan, S. (2016). Design of RC Beam With and Without Welded Mesh as Shear Reinforcement in Flexural and Shear Behaviour. Int. J. of Adv. Eng. Research and Tech. (IJAERT), 4(6), 214-217.

Indonesia, S. N. (2013). Persyaratan beton struktural untuk bangunan gedung. SNI, 2847, 2013.

Elsayed, A. A. Z. (2016). Behavior of Reinforced Concrete T. Beams with Welded Mesh Reinforcement under Repeated Load. IOSR Journal of Mechanical and Civil Engineering (IOSR-JMCE), 13(4), 54-71.
Griezic, A., Cook, W. D., \& Mitchell, D. (1994). Tests to Determine Performance of Deformed Welded Wire Fabric Stirrups. Structural Journal, 91(2), 211-220.

Lin, C. H., \& Perng, S. M. (1998). Flexural behavior of concrete beams with welded wire fabric as shear reinforcement. Structural Journal, 95(5), 540-546.

Mansur, M. A., Lee, C. K., \& Lee, S. L. (1987). Deformed wire fabric as shear reinforcement in concrete beams. Structural Journal, 84(5), $392-$ 399.

Nithin, K. R. \& Kumar, N. S. (2016). Flexural Behaviour of Self Compacting Concrete Beam using Welded Wire Mesh as Shear Reinforcement. Int. Journal of Sci. and Research (IJSR), 5(6), 189194.

Park, R. \& Paulay, T. (1975). Reinforced concrete structure. A Wiley-Interscience Publication, New York.

Pincheira, J. A., Rizkalla, S. H., \& Attiogbe, E. K. (1989). Performance of Welded Wire Fabric as Shear Reinforcement under Cyclic Loading. ACI Structural Journal, 86(6), 728-735.

Saatcioglu, M., \& Grira, M. (1999). Confinement of Reinforced Concrete Columns with Welded Reinforced Grids. Structural Journal, 96(1), 29-39.

Sudarsana, I. K., Saputra, I. G. O., \& Astri, P. A. R. (2016, Oktober). Kapasitas dan Daktilitas Aksial Kolom Penampang Pipih dengan Tulangan Transversal dari Galvanized Welded Wire Fabric $(G-W W F)$. In Konferensi Nasional Teknik Sipil 10 (Konteks10) (pp 237-244), Departement of Civil Engineering, Universitas Atmajaya Yogyakarta, Yogyakarta, Indonesia.

Tavio, Kusuma, B. \& Suprobo, P. (2012). Experimental Behavior of Concrete Columns Confined by Welded Wire Fabric as Transverse Reinforcement under Axial Compression. ACI Structural Journal, 109(3), 339-347.

Wight, J. K. \& MacGregor, J. (2012). Reinforced concrete: mechanics and material ( $6^{\text {th }}$ ed.). Pearson, Boston.

Xuan, X, Rizkalla, S, \& Maruyama, K. (1988). Effectiveness of Welded Wire Fabric as Shear Reinforcement in Pretensioned Prestressed Concrete T-Beams. ACI Str. Journal, July-August, 429-436. 